\title{
ANTINUCLEAR ANTIBODY AND RHEUMATOID FACTOR IN SILICA-EXPOSED WORKERS
}

\author{
Omid AMINIAN, Seyed AKBAR SHARIFIAN, Ramin MEHRDAD, \\ Khosro SADEGHNIYAT HAGHIGHI, and Maria MAZAHERI \\ Department of Occupational Medicine, Tehran University of Medical Sciences, Tehran, Iran
}

Received in July 2008

Accepted in May 2009

\begin{abstract}
A lot of workers in industries such as foundry, stonecutting, and sandblasting are exposed to higher than permissible levels of crystalline silica. Various alterations in humoral immune function have been reported in silicosis patients and workers exposed to silica dust. The aim of this study was to measure antinuclear antibody (ANA) and rheumatoid factor (RF) levels in foundry workers exposed to silica and to compare them with a control group without such exposure. ANA and RF were measured in 78 exposed and 73 non-exposed workers, and standard statistical methods were used to compare them. The two groups did not significantly differ in age and smoking. Mean work duration of the exposed and non-exposed workers was (14.9 \pm 4.72$)$ years and $(12.41 \pm 6.3)$ years, respectively. Ten exposed workers had silicosis. ANA was negative in all workers in either group. Its mean titer did not differ significantly between the exposed and control workers [(0.39 \pm 0.15$) \mathrm{IU} \mathrm{mL}^{-1}$ vs. $(0.36 \pm 0.17) \mathrm{IU} \mathrm{mL}^{-1}$, respectively]. $\mathrm{RF}$ was positive in two workers of each group. Other studies have reported an increase in ANA and RF associated with exposure to silica dust and silicosis.

In contrast, our study suggests that exposure to silica dust does not increase the level of ANA and RF in exposed workers.
\end{abstract}

KEY WORDS: autoimmune changes, foundry workers, humoral alterations, rheumatoid diseases, silicosis

The abundance of silica in the environment is second only to oxygen and second to none in the Earth crust. A lot of workers are exposed to it in different industries such as foundry, stonecutting, and sandblasting (1). Exposure to crystalline silica is not only a known cause of lung fibrosis and silicosis, but it may also pose a risk of autoimmune changes and rheumatoid diseases such as rheumatoid arthritis, scleroderma, and vasculitis (2). Foundry workers are exposed to different chemicals, the most important of which is respiratory exposure to silica dust $(3,4)$. Long-term exposure to silica can cause silicosis, and there have also been reports of alterations in humoral and cellular immunity $(5,6)$. In a study by Zone and Rom, workers exposed to mineral dusts were diagnosed hypergammaglobulinaemia, the elevetad production of auto-antibodies and immune complexes (7). Long-term exposure to silica dust can increase anti-neutrophil cytoplasmic antibodies, but only in silicosis patients. These antibodies will not rise if the exposure does not cause silicosis (8).

A relationship has been reported between silicosis and progressive systemic sclerosis and between silicosis and a rise in ANA and RF titer (9). In sandblast workers, a rise in ANA has been reported after more than six years of exposure to crystalline silica (10). A rise in ANA titer has also been reported following exposure to asbestos (11).

Immune disorders and specifically auto-immune disorders were observed in silicosis patients with 
long-term exposure to silica dust and in patients who had silicon implants (12).

Several studies reported humoral immune responses and some degree of auto-antibody increase in silicosis patients, even before the disease was clinically diagnosed $(13,14)$. Silicosis patients with multiple chest X-ray (CXR) opacities showed an increase in the ANA level $(13,15)$. Increase in polyclonal immunoglobulins both in blood and bronchoalveolar lavage fluid were also reported with silicosis (16).

There is a strong evidence supporting that exposure to crystalline silica produces several immune responses (12-14), but there are opposing views regarding the changes in RF and ANA levels following silica exposure.

The aim of this study was to measure ANA and RF levels in foundry workers exposed to silica and compare them with a control group without such exposure.

\section{SUBJECTS AND METHODS}

\section{Study Population}

This study was conducted in a foundry and metal producing factory in southern Tehran in 2006-2007. Workers occupationally exposed to silica dust were selected from sections such as metal melting, metal casting, pouring, shakeout, abrasive blasting, and finishing and cleaning. These workers rotated between these sections and did not wear proper respiratory protection most of the time. Of them 480 we randomly selected 78. For control we randomly selected 73 office workers who did not have any exposure to silica dust. Workers who, according to their pre-employment records, suffered from chronic diseases and autoimmune problems were excluded from the study.

All study subjects were male. The age of the exposed workers ranged from 28 to 55 years [mean \pm $\mathrm{SD}=(38.5 \pm 6.83)$ years $]$ and of controls from 26 to 52 years $[$ mean $\pm \mathrm{SD}=(37.1 \pm 8.18)$ years]. Employment duration was $(14.9 \pm 4.7)$ years (range 9 to 30 years) for the exposed workers and $(12.41 \pm 6.3)$ years (range 5 to 28 years) for controls. Nineteen exposed workers and 16 controls were smokers (Table 1).

All subjects were familiarised with the study and gave informed consent. All were interviewed by a physician, who reviewed their medical records and filled in the American Thoracic Society (ATS) standard respiratory questionnaire based on their answers.

All subjects were examined by an occupational medicine specialist, and the exam results recorded. Information gathered from the questionnaire and medical records included demographic data, occupational history, drug use data, medical history including joint and skin problems, auto-immune diseases, cough, dyspnoea, and other relevant symptoms. Particularly important were the history of chronic (everyday) cough for 3 months in the past year and a feeling of chest tightness while walking with people of the same age who were symptom-free.

Any history of joint swelling, pain or stiffness, skin erythema, sclerotic skin, symptoms of Raynaud's phenomena, and other symptoms of auto-immune and malignant diseases were reviewed and recorded. None of the subjects had any of these symptoms.

Workers exposed to silica dust did a spirometry test between 9 a.m. and 1 p.m. with a portable spirometer (MIR Spirolab II A23-050). The test was done by a trained technician according to the ATS standards. Different respiratory problems such as restrictive,

Table 1 Demographic data and respiratory symptoms in foundry workers exposed to silica dust and in non-exposed controls

\begin{tabular}{lccc}
\hline $\begin{array}{l}\text { Demographic data and } \\
\text { respiratory symptoms }\end{array}$ & $\begin{array}{c}\text { Exposed workers } \\
(\mathbf{n = 7 8 )}\end{array}$ & $\begin{array}{c}\text { Non-exposed workers } \\
(\mathbf{n = 7 3 )}\end{array}$ & P-value $^{\mathbf{3}}$ \\
\hline Age / years & $38.5 \pm 6.8$ & $37.1 \pm 8.2$ & 0.25 \\
Employment duration / years $^{1}$ & $14.9 \pm 4.7$ & $12.41 \pm 6.3$ & 0.008 \\
Smoking $^{2}$ & $19(24.4 \%)$ & $16(22.9 \%)$ & 0.72 \\
Chronic cough $^{2}$ & $18(22.8 \%)$ & $3(4.2 \%)$ & 0.001 \\
Dyspnoea $^{2}$ & $20(25.3 \%)$ & $3(4.2 \%)$ & 0.001 \\
\hline
\end{tabular}

${ }^{1}$ Data are presented as mean \pm standard deviation

${ }^{2}$ Data are presented as the number and percent of subjects

${ }^{3} P$-value less than 0.05 is considered statistically significant 
obstructive, or mixed were diagnosed based on the recorded forced vital capacity (FVC), forced expiratory volume in one second $\left(\mathrm{FEV}_{1}\right), \mathrm{FEV}_{1} / \mathrm{FVC}$, and other parameters.

All exposed workers had a standard CXR (posteroanterior and lateral) reported by a radiologist. An occupational medicine specialist familiar with the International Labour Organization classification of pneumoconioses reviewed the CXRs for nodular and fibrotic lesions.

A blood sample was drawn at the workplace by a lab technician and was sent to the lab in standard conditions. Because ANA immunofluorescence test was negative for all samples, we measured ANA titer using the standard enzyme-linked immunosorbent assay (ELISA) according to the method described by Hyashi et al. (17).

RF was measured using a quantitative method and compared to standard concentrations. A titer higher than $10 \mathrm{U} \mathrm{mL}^{-1}$ was considered positive (18).

\section{Sampling of respirable dust}

At least three random samples of respirable dust were collected from each workplace over a period of three months, and the total dust was measured using the gravimetric method. Collected samples were then sent to a laboratory for further analysis. Free crystalline silica was measured using X-ray diffraction. The standard permissible level is $5 \mathrm{mg} \mathrm{m}^{-3}$ for total dust and $0.1 \mathrm{mg} \mathrm{m}^{-3}$ for free crystalline silica.

\section{Data analysis}

Data were analysed using statistical software SPSS ${ }^{\circledR}$ version 16. Continuous variables were compared between the two groups using the $t$-test for normally distributed variables and using the Mann-Whitney test for non-normally distributed variables. Chi-square test was used to compare binomial variables between the two groups. $\mathrm{P}$ value of less than 0.05 was considered statistically significant.

\section{RESULTS}

Mean age and smoking showed no statistically significant difference between the two groups, but mean employment duration was significantly higher in the exposed workers than controls.

Medical history and physical exam showed that 20 exposed workers $(25.3 \%)$ and three controls $(4.2 \%)$ had dyspnoea, while 18 exposed workers $(22.8 \%)$ and three controls $(4.2 \%)$ had chronic cough. Both symptoms were significantly different between the two groups (chi-square test, Table 1).

No subject complained about joint pain, arthritis, skin erythema, inflammation, sclerosis, or any other symptoms of auto-immune diseases.

On CXR, ten exposed workers with more than 15 years of work experience had diffuse nodular opacities in the upper and middle lobe. Of these, seven had low profusion of small opacities of less than three $\mathrm{mm}$ in diameter and three had medium to high profusion of opacities up to $10 \mathrm{~mm}$ in diameter.

Twelve exposed workers (15.3\%) had abnormalities in spirometry; four had obstructive, five restrictive, and three mixed abnormalities.

Immunofluorescence test was negative for ANA in both groups, and the quantitative ELISA method

Table 2 Quantitative comparison of ANA and $R F$

\begin{tabular}{|c|c|c|c|c|c|c|c|c|c|}
\hline \multirow{2}{*}{$\begin{array}{l}\text { Immunologic } \\
\text { markers }\end{array}$} & \multicolumn{3}{|c|}{ Exposure } & \multicolumn{3}{|c|}{$\begin{array}{c}\text { Chest X-ray of exposed } \\
\text { workers }\end{array}$} & \multicolumn{3}{|c|}{ Smoking } \\
\hline & $\begin{array}{c}\text { Yes } \\
(\mathrm{N}=78)\end{array}$ & $\begin{array}{c}\text { No } \\
(\mathrm{N}=73)\end{array}$ & $\mathbf{P}$ & $\begin{array}{c}\text { Normal } \\
(\mathrm{N}=68)\end{array}$ & $\begin{array}{c}\text { Abnormal } \\
\text { (silicosis) } \\
(\mathrm{N}=10)\end{array}$ & $\mathbf{P}$ & $\begin{array}{c}\text { Yes } \\
(\mathrm{N}=35)\end{array}$ & $\begin{array}{c}\text { No } \\
(\mathrm{N}=116)\end{array}$ & $\mathbf{P}$ \\
\hline \multicolumn{10}{|l|}{ ANA / IU mL $\mathrm{m}^{-1}$} \\
\hline Range & 0.15 to 0.25 & 0.1 to 0.8 & & 0.2 to 0.8 & 0.3 to 0.8 & & 0.3 to 0.7 & 0.25 to 0.8 & \\
\hline Mean \pm SD & $0.39 \pm 0.15$ & $0.36 \pm 0.17$ & 0.34 & $0.39 \pm 0.14$ & $0.37 \pm 0.18$ & 0.653 & $0.34 \pm 0.15$ & $0.39 \pm 0.16$ & 0.107 \\
\hline \multicolumn{10}{|l|}{$\mathrm{RF} / \mathrm{U} \mathrm{mL}^{-1}$} \\
\hline Range & 1.2 to 16.6 & 2.5 to 14.4 & & 2.2 to 9.3 & 1.2 to 16.6 & & 2.5 to 16.6 & 1.2 to 14.4 & \\
\hline Mean \pm SD & $2.40 \pm 2.47$ & $3.18 \pm 2.6$ & 0.06 & $2.24 \pm 1.34$ & $3.22 \pm 2.89$ & 0.318 & $3.48 \pm 3.38$ & $2.61 \pm 1.81$ & 0.149 \\
\hline
\end{tabular}

$P$-value less than 0.05 is considered statistically significant 
confirmed negative results. Mean ANA concentration did not significantly differ between the two groups. Of the ten cases with silicosis visible on CXR, all were ANA-negative. Mean ANA level did not significantly differ between them and other exposed workers with normal CXR (Table 2).

$\mathrm{RF}$ was positive in two exposed workers and two controls. Even though one silicosis patient had a positive RF finding, it was not significantly different from exposed workers with normal CXR. Mean RF was $3.22 \mathrm{U} \mathrm{mL}^{-1}$ in silicosis patients and $2.24 \mathrm{U}$ $\mathrm{mL}^{-1}$ in others, but the difference was not statistically significant (Mann-Whitney test; Table 2).

Quantitative changes of ANA and RF in smokers and non-smokers are shown in Table 2. Fisher's exact test showed a statistically significant difference in RF positive findings between smokers and non-smokers ( 3 vs. 1 , respectively; $\mathrm{P}=0.013$ ).

\section{Environmental sampling results}

Table 3 shows mean concentrations of total dust and free crystalline silica in ambient air in different workplace sections. Dust turned out to be higher than the national standard in all samples.

\section{DISCUSSION}

Several studies have reported immune humoral changes in silicosis patients (14). These changes may become evident even before clinical diagnosis of an autoimmune disease $(13,14)$.

Otuski et al. (14) showed that silicosis patients with high levels of membrane Fas mean fluorescent intensity (MFI) had low levels of anti-nuclear antibodies and those with high levels of ANA had lower levels of MFI.

Foundry workers run a relative high risk of exposure to free crystalline silica and of acquiring silicosis. In this study we assessed the effect of exposure to silica dust on changes in autoantibodies.
ANA was negative in all subjects, including silicosis patients, and quantitation showed no significant differences between exposed workers, controls, or silicosis patients. RF was positive in the same number of exposed and control workers. The single positive RF finding in a silicosis patient did not quantitatively differ from the exposed workers with normal CXR. Earlier studies reported a high prevalence of ANA in patients with late-stage silicosis (9), but in our study none of the patients were at this stage of the disease.

In a study on rheumatoid arthritis patients and a control group, no statistically significant difference was observed for silica dust exposure $(19,20)$. In contrast, another study reported crystalline silica exposure as an important risk factor for rheumatoid arthritis (21).

Albuquereque de Castro et al. (22) showed a significant increase in $\mathrm{IgG}$ in silica dust-exposed workers and silicosis patients than in subjects with normal CXR. This pointed to possible changes in specific and non-specific immune response to silica dust. Nagaoka et al. (23) found an increase in $\operatorname{IgG}$ levels in workers exposed to silica dust (with or without silicosis) compared to the control group.

Doll et al. (13) reported a positive RF finding in $28 \%$ of 53 silicosis patients and Nagaoka et al. (23) in $10.4 \%$ of 134 silicosis patients. Subra et al. (24) could not show any significant increase in RF, $\mathrm{C} 3$ and $\mathrm{C} 4$ complement components in the serum of silicosis patients. Jones et al. (9) reported high levels of ANA in silica dust-exposed workers, while other studies showed increased levels of ANA and RF with exposure to free silica (11).

In a study conducted by Albuqerque de Castro et al. (22) in Brazil, ANA and RF were positive in $20.6 \%$ and $3.4 \%$ of silica dust exposed workers, respectively, but no statistically significant difference was found between silicosis patients and exposed workers without silicosis.

Table 3 Total dust concentrations and of free crystalline silica in different foundry sections

\begin{tabular}{lcc}
\hline \multirow{2}{*}{ Sections } & Total dust concentration $/ \mathbf{~ m g ~ m}^{-3}$ & Free crystalline silica $/ \mathbf{~ m g ~ m}^{-3}$ \\
\cline { 2 - 3 } & Mean \pm SD & Mean \pm SD \\
\hline Metal melting and pouring & $16 \pm 1.85$ & $1.2 \pm 0.25$ \\
Casting, shakeout & $21 \pm 2.08$ & $2.3 \pm 0.32$ \\
Cleaning and finishing (abrasive & $51 \pm 4.90$ & $7.1 \pm 0.54$ \\
blasting) & & \\
\hline
\end{tabular}


About $75 \%$ of autoimmune diseases occur in women. In our study all participants were men, and this eliminated the possibility of a co-incidental high RF and ANA.

Jonsson et al. (25) have shown that smoking may affect the immune system, and that it is associated with increased RF. However, no such association was observed in our study.

\section{CONCLUSION}

Based on our study, RF and ANA are not suitable tests for evaluation of early immunologic changes in silica-exposed workers who do not have progressive silicosis or any symptoms of autoimmune diseases. More comprehensive studies on other immunologic factors in silicosis patients and silica dust-exposed workers are required to assess autoimmune effects of free silica.

\section{Acknowledgement}

This study has been supported by the Tehran University of Medical Sciences (TUMS). The authors wish to express their gratitude to the staff of the Occupational Medicine Department for their kind collaboration.

\section{REFERENCES}

1. Ladou J. Current Occupational and Environmental Medicine. $3^{\text {rd }}$ ed. New York (NY): McGraw Hill/Appleton \& Lange; 2004.

2. Rom WN. Occupational and Environmental Medicine. $4^{\text {th }}$ ed. Philadelphia: Lippincott Williams \& Wilkins; 2007.

3. Basaran N, Shubair M. Alteration in immune parameters in foundry and pottery workers. Toxicology 2002;178:81-8.

4. Sanches RJ, Wichmann I, Salaberri J. Multiple clinical and biological autoimmune manifestations in 50 workers after occupational exposure to silica. Ann Rheum Dis 1993;52:534-8

5. Michael IL, Meryl HK. Preface to occupational immunology. Int Immunopharmacol 2002;2:161-2.

6. Parks CG, Conrad K, Cooper GS. Occupational exposure to crystalline silica and autoimmune disease. Environ Health Persp 1999;107:793-802.

7. Zone JJ, Rom WN. Circulating immune complexes in asbestos workers. Environ Res 1985;37:383-9.

8. Bartunkova J, Pelclova D. Exposure to silica and risk of ANCA-associated vasculitis. Am J Ind Med 2006;49:56976.

9. Jones RN, Turner-Warwick M, Ziskind M, Weill H. High prevalence of antinuclear antibodies in sandblasters' silicosis. Am Rev Respir Dis 1976;393-5.

10. Sanchez-Roman J, Wichmann I, Salaberri J, Varela
JM, Nuñez-Roldan A. Multiple clinical and biological autoimmune manifestations in 50 workers after occupational exposure to silica. Ann Rheum Dis 1993;52:534-8.

11. Huaux F. New development in the understanding of immunology in silicosis. Curr Opin Allergy Clin Immunol 2007;7:168-73.

12. Bar-Meir E, Eherenfeld M, Shoenfeld Y. Silicone gel breast implants and connective tissue disease- a comprehensive review. Autoimmunity 2003;36:193-7.

13. Doll NJ, Stankus RP, Hughes J, Weill H, Gupta RC, Rodriguez M, Jones RN, Alspaugh MA, Salvaggio JE. Immune complexes and autoantibodies in silicosis. J Allergy Clin Immunol 1981;68:281-5.

14. Otsuki T, Miura Y, Nishimura Y, Hyodoh F, Takata A, Kusaka M, Katsuyama H, Tomita M, Ueki A, Kishimoto T. Alteration of fas and fas-related molecules in patients with silicosis. Exp Biol Med (Maywood) 2006;231:522-33.

15. Lavras Costallat LT, De Capitani E, Zambon L. Pulmonary silicosis and systemic lupus erythematosus in men: a report of two cases. Joint Bone Spine 2002;69:68-71.

16. Ueki $\mathrm{A}$, Isozaki $\mathrm{Y}$, Tomokuni $\mathrm{A}$, Tanaka $\mathrm{S}$, Otsuki $\mathrm{T}$, Kishimoto T, Kusaka M, Aikoh T, Sakaguchi H, Hydoh F. Autoantibodies detectable in the sera of silicosis patients. The relationship between the anti-topoisomerase I antibody response and HLA-DQB1*0402 allele in Japanese silicosis patients. Sci Total Environ 2001;270:141-8.

17. Hayashi N, Kawamoto T, Mukai M, Morinobu A, Koshiba M, Kondo S, Maekawa S, Kumagai S. Detection of antinuclear antibodies by use of an enzyme immunoassay with nuclear HEp-2 cell extract and recombinant antigens: comparison with immunofluorescence assay in 307 patients. Clin Chem 2001;47:1649-59.

18. Lutteri L, Malaise M, Chapelle JP. Comparison of secondand third-generation anti-cyclic citrullinated peptide antibodies assays for detecting rheumatoid arthritis. Clin Chim Acta 2007;386:76-81.

19. Pfau JC, Sentissi JJ, Weller G, Putnam EA. Assessment of autoimmune responses associated with asbestos exposure in Libby, Montana, USA. Environ Health Persp 2005;113:2530.

20. Turner S, Cherry N. Rheumatoid arthritis in workers exposed to silica in the pottery industry. Occup Environ Med 2000;57:443-7.

21. Stolt P, Källberg H, Lundberg I, Sjögren B, Klareskog L, Alfredsson L; EIRA study group. Silica exposure is associated with increased risk of developing rheumatoid arthritis: results from the Swedish EIRA study. Ann Rheum Dis 2005;64:582-6.

22. Albuquereque de Castro H, Gimenes C, Lemle A. Immunoglobulins, complements and autoantibodies in 58 workers exposed to silica. J Bras Pneumol 2004;30:201-6.

23. Nagaoka T, Tobata M, Kobayashi K, Okada A. Studies on production of anticollagen antibodies in silicosis. Environ Res 1993;60:12-29.

24. Subra JF, Renier G, Reboul P, Tollis F, Boivinet R, Schwartz $\mathrm{P}$, Chevailler A. Lymphopenia in occupational pulmonary silicosis with or without autoimmune disease. Clin Exp Immunol 2001;126:540-4.

25. Jónsson T, Thorsteinsson J, Valdimarsson H. Does smoking stimulate rheumatoid factor production in non-rheumatic individuals? Acta Pathol Microbiol Immunol Scand 1998;106:970-4. 
Sažetak

\section{RAZINE ANTINUKLEARNOGA ANTITIJELA I REUMATOIDNOGA FAKTORA U RADNIKA IZLOŽENIH SILICIJEVU DIOKSIDU}

Mnogi su radnici izloženi kristalnomu silicijevu dioksidu u razinama iznad dopuštenih. U oboljelih od silikoze i radnika izloženih prašinama koje sadržavaju silicijev dioksid zamijećen je niz oštećenja humoralne obrane. Budući da su radnici u ljevaonicama izloženi visokim razinama kristalnoga silicijeva dioksida, u njih bismo očekivali ovakve humoralne poremećaje.

Cilj je ovog ispitivanja bio izmjeriti i usporediti razine antinuklearnih protutijela (ANA) i reumatoidnoga faktora $(\mathrm{RF}) \mathrm{u}$ krvi radnika u ljevaonici izloženih silicijevu dioksidu i neizložene kontrolne skupine. ANA i RF izmjereni su u 78 izloženih radnika i 73 neizložena radnika te su uspoređeni s pomoću standardnih statističkih metoda. Dvije se skupine nisu bitno razlikovale u broju pušača i u dobi. Prosječna duljina radnog vijeka izloženih radnika bila je $(14,9 \pm 4,72)$ godine, a neizloženih $(12,41 \pm 6,3)$ godine. Deset izloženih radnika imalo je silikozu. Nalazi ANA bili su negativni u obje skupine radnika. Srednja vrijednost titra ANA iznosila je $(0,39 \pm 0,15) \mathrm{IU} \mathrm{mL}^{-1} \mathrm{u}$ izloženih ispitanika, a $(0,36 \pm 0,17) \mathrm{IU} \mathrm{mL}^{-1} \mathrm{u}$ kontrola, što je statistički zanemariva razlika. Nalaz RF-a bio je pozitivan u dva izložena te dva kontrolna radnika.

Naše ispitivanje upućuje na to da prašine silicijeva dioksida ne uzrokuju porast razina ANA i RF-a u izloženih radnika.

KLJUČNE RIJEČI: autoimunosni sustav, humoralne promjene, ljevaonica, reumatoidne bolesti, silikoza

\section{CORRESPONDING AUTHOR:}

Omid Aminian, MD, associate professor

Department of Occupational Medicine, Faculty of Medicine Tehran University of Medical Sciences, Tehran, Iran

E-mail:oaminian@sina.tums.ac.ir 